\title{
FAKTOR-FAKTOR YANG MEMPENGARUHI MINAT INVESTASI DI PASAR MODAL SYARIAH PADA MAHASISWA FEBI IAIN FATTAHUL MULUK PAPUA
}

\author{
Rani Nur Indah Lestari \\ IAIN Fattahul Muluk Papua \\ raninurindahlestari@gmail.com \\ Miftahul Huda \\ IAIN Fattahul Muluk Papua \\ miftah.huda22@yahoo.co.id \\ Abdul Karman \\ IAIN Fattahul Muluk Papua \\ abdul.karman.1988@gmail.com
}

\begin{abstract}
This study aims to determine the factors that influence the intention of investment namely the encouragement from within individuals, social motive, and emotional factor partially and simultaneously on the intention of students' investment in Islamic capital markets. This research method is quantitative. The population in this study is students of Islamic Economics and Business Faculty in IAIN Fattahul Muluk Papua which consisted of Islamic economics and Islamic banking study programs from 2016 to 2019. The sample in this study is 76 students. The sampling technique uses simple random sampling. Data collection in this study uses the questionnaire method. Data analysis techniques used in this study is multiple linear regression using SPSS 16.0 application. The results of this study indicate that: (1) Encouragement from within the individual has a significant effect on the intention of investment, with a significance value of 0,000 . (2) Social motive significantly influence the intention of investment, with a significance value of 0,000 . (3) Emotional factor do not significantly influence the intention of investment, with a significance value of 0.168. (4) Encouragement from within individuals, social motive, and emotional factor simultaneously influence the intention of investment of Islamic Economics and Business Faculty students in IAIN Fattahul Muluk Papua.
\end{abstract}

Keywords: Encouragement from the Individual, Social Motives, Emotional Factors, Investment Interest in Islamic Capital Markets

\begin{abstract}
ABSTRAK
Penelitian ini bertujuan untuk mengetahui faktor-faktor yang mempengaruhi minat investasi yaitu dorongan dari dalam diri individu, motif sosial dan faktor emosional secara parsial dan simultan berpengaruh terhadap minat investasi di pasar modal syariah pada mahasiswa. Metode penelitian ini adalah kuantitatif. Populasi dalam penelitian ini adalah mahasiswa Fakultas Ekonomi dan Bisnis Islam IAIN Fattahul Muluk Papua yang terdiri dari program studi ekonomi syariah dan perbankan syariah angkatan 2016 sampai dengan 2019. Sampel dalam penelitian ini sebanyak 76
\end{abstract}


mahasiswa. Teknik pengambilan sampel menggunakan simple random sampling. Pengumpulan data pada penelitian ini menggunakan metode kuesioner. Teknik analisis data yang digunakan dalam penelitian ini adalah regresi linier berganda. Uji analisis data menggunakan aplikasi SPSS 16.0. Hasil dari penelitian ini menunjukkan bahwa: (1) Dorongan dari dalam diri individu berpengaruh signifikan terhadap minat investasi, dengan nilai signifikansi 0.000. (2) Motif sosial berpengaruh signifikan terhadap minat investasi, dengan nilai signifikansi 0.000. (3) Faktor emosional tidak berpengaruh signifikan terhadap minat investasi, dengan nilai signifikansi 0.168. (4) Dorongan dari dalam diri individu, motif sosial, dan faktor emosional berpengaruh secara simultan terhadap minat investasi di pasar modal syariah pada mahasiswa Fakultas Ekonomi dan Bisnis Islam IAIN Fattahul Muluk Papua.

Kata Kunci: Dorongan Dari Dalam Diri Individu, Motif Sosial, Faktor Emosional, Minat Investasi di Pasar Modal Syariah

\section{PENDAHULUAN}

Indonesia adalah negara dengan Sumber Daya Alam (SDA) yang melimpah, populasi yang besar, dan memiliki Sumber Daya Manusia (SDM) yang produktif. Industri pengelolaan investasi Indonesia juga mengalami pertumbuhan sangat pesat dalam kurun waktu 2012 sampai dengan 2017. Industri tersebut merupakan subsektor pasar modal yang menawarkan jasa pengelolaan dana oleh manajer investasi. (Kusumaningtuti dan Cecep, 2018) Pada tahun 2017 Indonesia juga mendapatkan rating investment grade alias layak investasi dari lembaga pemeringkat internasional Standard \& Poor's (S\&P). Oleh karena itu, Indonesia sampai saat ini masih berjuang untuk memajukan pasar modalnya.

Pertumbuhan investor di pasar modal Indonesia sebagai salah satu alternatif pilihan untuk berinvestasi dinilai cukup baik. PT. Kustodian Sentral Efek Indonesia (KSEI) sebagai Lembaga Penyimpanan dan Penyelesaian (LPP) di pasar modal Indonesia yang menyediakan layanan jasa Kustodian sentral dan penyelesaian transaksi efek yang teratur, wajar, dan efisien, sesuai amanat Undang-Undang Nomor 8 Tahun 1995 tentang Pasar Modal telah mencatat total investor yang terekam sebagai Single Investor Identification (SID) mencapai 1.971.213 per Juni 2019. Kenaikan jumlah investor di pasar modal didorong oleh tingginya partisipasi generasi milenial, serta kian mudahnya masyarakat mengakses pasar modal seiring perkembangan teknologi. Akan tetapi menurut studi terakhir yang dirilis Badan Pusat Statistik (BPS) tahun 2010, Indonesia memiliki jumlah penduduk 237,6 juta orang. Jika dibandingkan dengan jumlah investor yang ada pada saat ini, investor di pasar modal masih sangat rendah. 


\section{Gambar 1: Grafik Pertumbuhan Jumlah Investor}

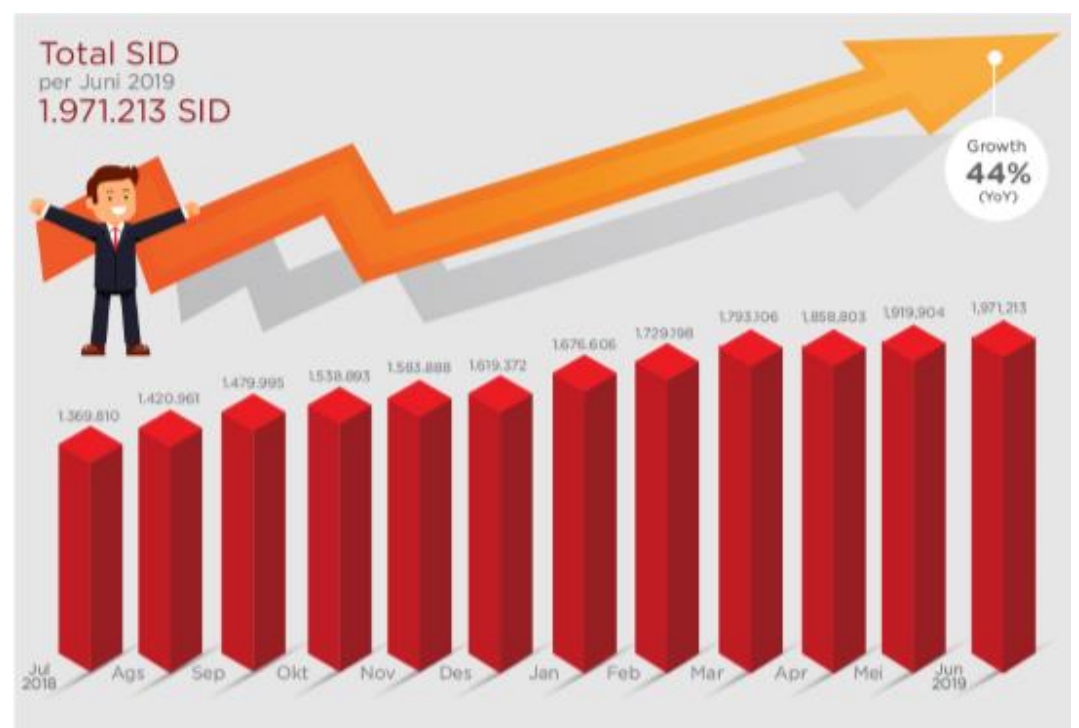

Sumber: KSEI, 2019

Pada tahun 2015, Bursa Efek Indonesia melaksanakan survei potensi calon investor saham di sembilan kota besar Indonesia dan hasilnya adalah terdapat $49 \%$ responden yang memahami mekanisme berinvestasi dan $20 \%$ menyatakan mulai tertarik untuk mulai berinvestasi di saham. Sebagian besar calon investor memiliki karakteristik risiko yang rendah (mencari aman) di mana 53\% responden menyebutkan ingin berinvestasi pada instrumen yang menyerupai tabungan dan deposito berjangka di mana nilainya stabil, dan sekitar $22 \%$ responden ingin memperoleh tingkat pengembalian yang lebih tinggi dari tabungan dan deposito berjangka serta tidak nyaman dengan fluktuasi investasi jangka pendek. Hanya $4 \%$ responden yang ingin nilai investasinya tumbuh pesat dan memperoleh tingkat pengembalian semaksimal mungkin serta dapat menerima fluktuasi negatif termasuk kemungkinan kehilangan nilai invetasi awal. Hal ini menjadi tantangan tersendiri karena di sisi lain calon investor menginginkan suatu produk investasi yang bisa dengan cepat menghasilkan keuntungan dengan risiko yang seminimal mungkin (Kusumaningtuti dan Cecep, 2018).

Bursa Efek Indonesia (BEI) selaku pengelola dan dalam mewujudkan tujuannya menyelenggarakan perdagangan efek di pasar modal Indonesia terus melakukan pengembangan bisnis dan pasar. Pengembangan tersebut dilaksanakan oleh direktur pengembangan yang bertanggung jawab atas kegiatan operasional yang terkait dengan pengelolaan riset pasar modal dan ekonomi, pengembangan produk dan usaha, kegiatan pemasaran serta kegiatan edukasi dan sosialisasi. Oleh karena itu, Bursa Efek Indonesia (BEI) melakukan pendekatan langsung kepada calon pelaku pasar melalui beberapa jalur. Salah satunya dengan pendirian Kantor Perwakilan BEI di daerah-daerah yang potensial dan pembukaan galeri investasi. Pendirian Kantor Perwakilan BEI dimaksudkan sebagai perintis bagi Anggota Bursa untuk beroperasi di suatu daerah yang potensial atau daerah-daerah yang memiliki potensi besar untuk lebih 
dikembangkan. Pada tahun 2016, Bursa Efek Indonesia (BEI) memiliki 25 Kantor Perwakilan BEI dan 240 galeri investasi, di mana 163 galeri investasi berada di Ibukota provinsi dan 77 galeri investasi berada di Kabupaten atau Kotamadya (Kusumaningtuti dan Cecep, 2018).

Sedangkan dalam praktiknya, Bursa efek Indonesia (BEI), Kustodian Sentral Efek Indonesia (KSEI) dan Kliring Penjamin Efek Indonesia (KPEI) selaku SelfRegulatory Organization (SRO) dan perusahaan efek telah melakukan serangkaian kegiatan untuk meningkatkan literasi dan inklusi di sektor pasar modal. Beberapa program tersebut antara lain Gerakan Nasional Cinta (Genta) Pasar Modal, Galeri Investasi, Sekolah Pasar Modal, Yuk Nabung Saham, Penggunaan e-KTP sebagai SID dan program-program edukasi lainnya (Kusumaningtuti dan Cecep, 2018).

Dari banyaknya program edukasi yang diprakarsai oleh PT. Bursa Efek Indonesia (BEI) bersama stakeholder lainnya, salah satunya adalah galeri investasi. Galeri Investasi BEI adalah sarana untuk memperkenalkan Pasar Modal sejak dini kepada dunia akademisi. Galeri Investasi BEI berkonsep 3 in 1 yang merupakan kerja sama antara BEI, Perguruan Tinggi dan Perusahaan Sekuritas diharapkan tidak hanya memperkenalkan Pasar Modal dari sisi teori saja akan tetapi juga praktiknya. Kedepannya melalui Galeri Investasi BEI yang menyediakan real time information untuk belajar menganalisis aktivitas perdagangan saham, diharapkan dapat menjadi jembatan menuju penguasaan ilmu pengetahuan beserta praktiknya di pasar modal (Kusumaningtuti dan Cecep, 2018).

Institut Agama Islam Negeri (IAIN) Fattahul Muluk Papua, merupakan salah satu perguruan tinggi yang telah mempunyai galeri investasi yang diresmikan pada tanggal 29 Oktober 2019. Peresmian galeri tersebut ditandai dengan penandatanganan surat perjanjian kerja sama antara Institut Agama Islam Negeri (IAIN) Fattahul Muluk Papua dengan Bursa Efek Indonesia (BEI) Kantor Perwakilan Papua dan PT. Phintraco Sekuritas serta menggelar acara pelantikan pengurus Galeri Investasi Syari'ah Bursa Efek Indonesia Institut Agama Islam Negeri (IAIN) Fattahul Muluk Papua sekaligus mengadakan seminar cerdas berinvestasi di pasar modal dengan mengundang beberapa narasumber di bidangnya. Dibukanya galeri investasi tersebut, diharapkan dapat menjadi wadah bagi mahasiswa agar lebih mudah lagi untuk berinvestasi.

Berdasarkan pengamatan sebelumnya, terdapat fenomena yang terjadi di kalangan mahasiswa tentang investasi salah satunya mahasiswa yang memiliki sedikit pemahaman tentang investasi di pasar modal dan enggan atau belum membuka account untuk melakukan investasi dengan alasan takut. Hal tersebut disebabkan karena beberapa hal diantaranya, kurangnya pemahaman investasi, takut akan sebuah risiko yang dihadapi, tingkat keuntungan yang belum pasti, besaran jumlah modal yang dibutuhkan, dan kurangnya pelatihan tentang investasi menjadi kendala bagi mahasiswa. Timbul berbagai macam pemikiran mahasiswa yang bisa mendorong minat mahasiswa untuk berinvestasi atau sebaliknya. 
Penelitian ini bertujuan untuk menentukan faktor-faktor yang mempengaruhi minat investasi di pasar modal syariah pada mahasiswa FEBI IAIN Fattahul Muluk Papua, di mana pengetahuan akan investasi masih tergolong baru dengan wilayah penduduk mayoritas non-muslim. Sebagian besar penelitian seperti yang dilakukan oleh Dinda (2018) tentang minat investasi di pasar modal dan beberapa penelitian yang dilakukan oleh Hayatul Fajri (2018), Laili Karima (2018), Sartika Susanti, dkk (2018), Ahmad Dahlan Malik (2017) tentang minat berinvetasi di pasar modal syariah di wilayah penduduk mayoritas muslim. Hasil penelitian ini dapat berkontribusi sebagai referensi tentang produk investasi syariah untuk menentukan minat investasi di pasar modal syariah, serta sumber informasi bagi pemerintah, lembaga yang terkait dengan penyelenggaraan perdagangan efek di Indonesia, dan pihak lain yang tertarik dengan produk investasi syariah dan pengembangannya. Oleh karena itu penelitian ini dilakukan berdasarkan pertanyaan-pertanyaan penelitian berikut: 1) Apakah dorongan dari dalam diri individu mempengaruhi minat investasi di pasar modal syariah? 2) Apakah motif sosial mempengaruhi minat investasi di pasar modal syariah? 3) Apakah faktor emosional mempengaruhi minat investasi di pasar modal syariah? 4) Apakah dorongan dari dalam diri individu, motif sosial, faktor emosional secara simultan mempengaruhi minat investasi di pasar modal syariah?

\section{KAJIAN LITERATUR}

\subsection{Minat}

a. Pengertian Minat

Abdul Rahman Shaleh dan Muhbib Abdul Wahab, mendefinisikan minat sebagai suatu kecenderungan untuk memberikan perhatian kepada orang dan bertindak terhadap orang, aktivitas atau situasi yang menjadi objek dari minat tersebut dengan disertai perasaan senang (Abdul dan Muhbib, 2004).

Ciri-ciri orang yang berminat untuk berinvestasi dapat diketahui dengan seberapa berusahanya mereka dalam mencari tahu tentang suatu jenis investasi, mempelajari dan kemudian mempraktikannya. Kusmawati juga menyatakan bahwa minat investasi adalah keinginan untuk mencari tahu tentang jenis suatu investasi dimulai dari keuntungan, kelemahan, kinerja investasi dan lain sebagainya. Ciri lain yang dapat dilihat adalah seseorang akan berusaha meluangkan waktu untuk mempelajari lebih jauh tentang investasi atau langsung mencoba melakukan investasi, bahkan menambah porsi investasi yang sudah ada (Kusmawati, 2011).

b. Faktor-Faktor Timbulnya Minat

Ada beberapa faktor yang mempengaruhi timbulnya minat. Crow dan Crow berpendapat ada tiga faktor yang menjadi timbulnya minat, yaitu (Abdul dan Muhbib, 2004): 
1) Dorongan dari dalam diri individu, misal dorongan untuk makan. Dorongan untuk makan akan membangkitkan minat untuk bekerja atau mencari penghasilan, minat terhadap produksi makanan dan lain-lain. Dorongan ingin tahu atau rasa ingin tahu akan membangkitkan minat untuk membaca, belajar, menuntut ilmu, melakukan penelitian dan lainlain.

2) Motif sosial, dapat menjadi faktor yang membangkitkan minat untuk melakukan suatu aktivitas tertentu. Misalnya minat terhadap pakaian timbul karena ingin mendapatkan persetujuan atau penerimaan dan perhatian orang lain. Minat untuk belajar atau menuntut ilmu pengetahuan timbul karena ingin mendapat penghargaan dari masyarakat, karena biasanya yang memiliki ilmu pengetahuan cukup luas (orang pandai) mendapat kedudukan yang tinggi dan terpandang dalam masyarakat.

3) Faktor emosional, minat mempunyai hubungan yang erat dengan emosi. Bila seseorang mendapatkan kesuksesan pada aktivitas akan menimbulkan perasaan senang dan hal tersebut akan memperkuat minat atas aktivitas tersebut, sebaliknya suatu kegagalan akan menghilangkan minat terhadap hal tersebut.

\subsection{Pasar Modal Syariah}

a. Pengertian Pasar Modal Syariah

Pasar modal syariah adalah kegiatan yang bersangkutan dengan penawaran umum dan perdagangan efek, perusahaan publik yang berkaitan dengan efek yang diterbitkannya serta lembaga dan profesi yang berkaitan dengan efek yang menjalankan kegiatannya sesuai dengan prinsip-prinsip syariah (Ikit et al, 2019).

b. Prinsip Pasar Modal Syariah

Dalam operasional pasar modal syariah harus mengikuti prinsipprinsip syariah. Prinsip-prinsip syariah dalam Fatwa Dewan Syariah Nasional (DSN) Nomor: 40/DSN-MUI/X/2003 menjelaskan (Ikit et al, 2019):

1) Perjudian dan permainan yang tergolong judi atau perdagangan yang dilarang.

2) Lembaga keuangan konvensional (ribawi), termasuk perbankan dan asuransi konvensional.

3) Produsen, distributor, serta pedagang makanan dan minuman yang haram.

4) Jual beli risiko yang mengandung unsur ketidakpastian (gharar) dan judi (maisir).

5) Memproduksi, mendistribusikan, memperdagangkan, dan atau menyediakan antara lain: a) barang atau jasa haram zatnya (haram lidzatihi), b) barang atau jasa haram bukan karena zatnya (haram lighairihi) yang ditetapkan oleh Dewan Syariah Nasional - Majelis Ulama Indonesia, c) barang atau jasa yang merusak moral dan bersifat mudarat. 
6) Melakukan investasi pada emiten (perusahaan) yang pada saat transaksi tingkat (nisbah) hutang perusahaan kepada lembaga keuangan ribawi lebih dominan dari modalnya.

c. Karakteristik Pasar Modal syariah

Dalam Fatwa DSN MUI No.40/DSN-MUI/X/2003 Tentang Pasar Modal dan Pedoman Umum Penerapan Prinsip Syariah di Bidang Pasar Modal. Fatwa tersebut menjelaskan perusahaan (emiten) yang menerbitkan efek syariah harus memenuhi kriteria yaitu (Ikit et al, 2019):

1) Jenis usaha, produk barang, jasa yang diberikan dan akad serta cara pengelolaan perusahaan emiten atau perusahaan publik yang menerbitkan efek syariah tidak boleh bertentangan dengan prinsip-prinsip syariah.

2) Emiten atau perusahaan publik yang bermaksud menerbitkan efek syariah wajib untuk menandatangani dan memenuhi ketentuan akad yang sesuai dengan syariah atas efek syariah yang dikeluarkan.

3) Emiten atau perusahaan publik yang menerbitkan efek syariah wajib menjamin bahwa kegiatan usahanya memenuhi prinsip-prinsip syariah dan memiliki Shariah Compliance Officer (SCO). Shariah Compliance Officer (SCO) adalah pihak atau pejabat dari suatu perusahaan atau lembaga yang telah mendapat sertifikasi dari DSN-MUI dalam pemahaman mengenai prinsip-prinsip syariah di pasar modal.

4) Dalam hal emiten atau perusahaan publik yang menerbitkan efek syariah sewaktu-waktu tidak memenuhi persyaratan tersebut di atas, maka efek yang diterbitkan dengan sendirinya sudah bukan sebagai efek syariah.

d. Instrumen Pasar Modal Syariah

Pasar modal syariah menawarkan beberapa produk yaitu saham syariah, reksadana syariah, sukuk dan efek syariah lainnya (Ikit et al, 2019).

1) Saham Syariah merupakan bukti kepemilikan atas suatu perusahaan yang memenuhi kriteria berdasarkan prinsip-prinsip syariah di pasar modal.

2) Reksadana Syariah adalah wadah yang dipergunakan untuk menghimpun dana dari masyarakat pemodal untuk selanjutnya diinvestasikan dalam portofolio efek oleh manajer investasi dan peraturan pelaksanaannya tidak bertentangan dengan prinsip-prinsip syariah di pasar modal.

3) Sukuk adalah efek syariah berupa sertifikat atau bukti kepemilikan yang bernilai sama dan mewakili bagian yang tidak tertentu (tidak terbagi/undivided share) atas aset berwujud tertentu, nilai manfaat atas aset berwujud tertentu baik yang sudah ada maupun yang akan ada, jasa yang sudah ada maupun yang akan ada, asset proyek tertentu, dan atau kegiatan investasi yang telah ditentukan.

4) Efek syariah lainnya adalah surat berharga yang termasuk Kontrak Investasi Kolektif Efek Beragun Aset (KIK EBA) syariah, surat berharga lainnya yang sesuai dengan prinsip-prinsip syariah. 
Berikut kerangka kerja yang digunakan dalam penelitian ini ditunjukkan pada gambar 2.

Gambar 2: Kerangka Teori

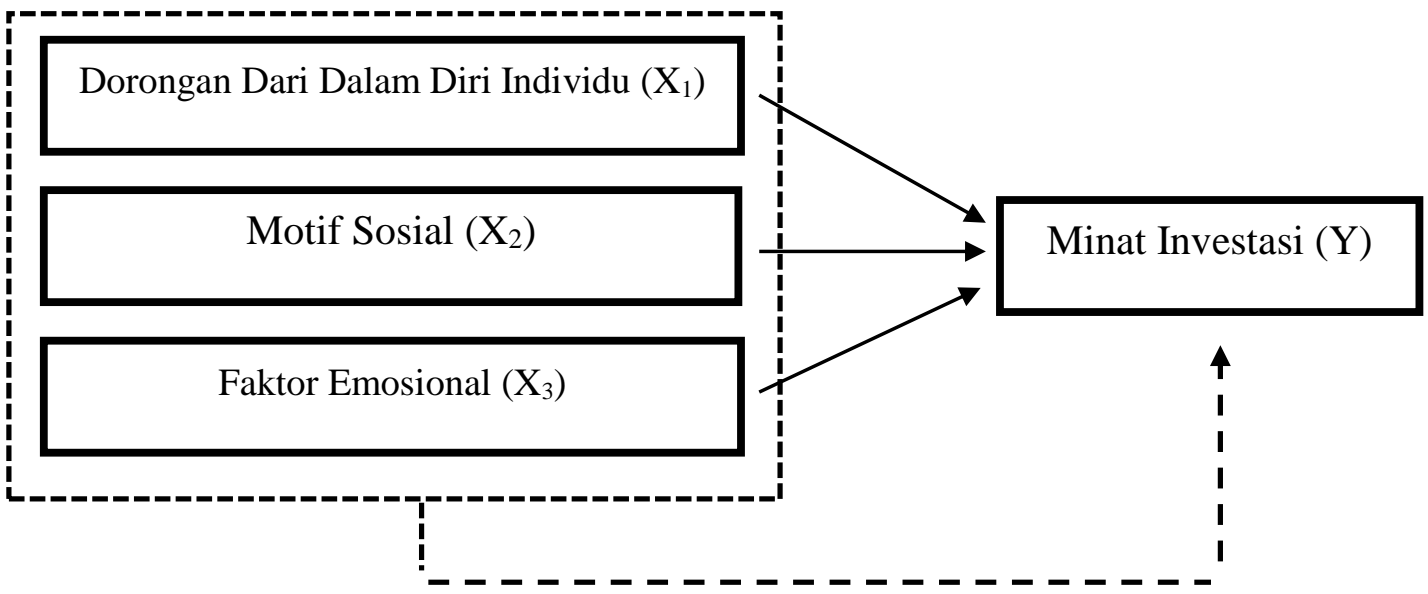

Berdasarkan kerangka teori di atas, maka penelitian ini memiliki empat hipotesis sebagai berikut:

$\mathrm{H}_{1}$ : Dorongan dari dalam individu berpengaruh signifikan dan positif terhadap minat investasi.

$\mathrm{H}_{2}$ : Motif sosial berpengaruh signifikan dan positif terhadap minat investasi.

$\mathrm{H}_{3}$ : Faktor emosional berpengaruh signifikan dan positif terhadap minat investasi.

$\mathrm{H}_{4}$ : Dorongan dari dalam individu, motif sosial, faktor emosional secara simultan berpengaruh signifikan dan positif terhadap minat investasi.

\section{METODE PENELITIAN}

\subsection{Populasi dan Sampel}

Adapun populasi dan sampel dalam penelitian ini. Populasi adalah wilayah generalisasi yang terdiri atas objek/subjek yang mempunyai kualitas dan karakteristik tertentu yang ditetapkan oleh peneliti untuk dipelajari dan kemudian ditarik kesimpulannya. Sampel adalah bagian dari jumlah dan karakteristik yang dimiliki oleh populasi tersebut (Sugiyono, 2017).

Tabel 1: Data Mahasiswa Program S1

Fakultas Ekonomi Bisnis Islam IAIN Fattahul Muluk Papua

\begin{tabular}{|c|l|c|c|c|c|c|}
\hline \multirow{2}{*}{ Fakultas } & \multirow{2}{*}{ Prodi } & \multicolumn{4}{|c|}{ Angkatan } & $\begin{array}{c}\text { Jumlah } \\
\text { Keseluruhan }\end{array}$ \\
\cline { 3 - 7 } & \multirow{3}{*}{ FEBI } & $\mathbf{2 0 1 6}$ & $\mathbf{2 0 1 7}$ & $\mathbf{2 0 1 8}$ & $\mathbf{2 0 1 9}$ & 142 \\
\hline & $\begin{array}{l}\text { Ekonomi } \\
\text { Syariah }\end{array}$ & 29 & 29 & 44 & 40 & 173 \\
\cline { 2 - 7 } & $\begin{array}{l}\text { Perbankan } \\
\text { Syariah }\end{array}$ & 49 & 44 & 43 & 37 & 315 \\
\hline \multicolumn{2}{|c|}{ Total } & 78 & 73 & 87 & 77 & 1 \\
\hline
\end{tabular}

Sumber: Fakultas FEBI IAIN Fattahul Muluk Papua Tahun 2020 
Populasi dalam penelitian ini adalah mahasiswa fakultas ekonomi dan bisnis islam yang terdiri dari program studi ekonomi syariah dan perbankan syariah angkatan 2016 sampai dengan 2019 yaitu berjumlah 315 mahasiswa. Dimana sampel diambil dari mahasiswa baik yang sudah memiliki akun investasi ataupun belum. Dalam menentukan besarnya sampel dalam penelitian ini didasarkan pada perhitungan yang dikemukakan oleh Slovin adalah sebagai berikut (Muhammad M, 2008):

$$
\mathrm{n}=\frac{N}{1+\left(N \times e^{2}\right)}
$$

Keterangan:

$\mathrm{N}$ : ukuran sampel

$\mathrm{N}$ : jumlah populasi yang diketahui yaitu 315 mahasiswa fakultas ekonomi dan bisnis ekonomi islam

e : margin error $(10 \%$ atau 0.1$)$

$$
\begin{aligned}
& \mathrm{n}=\frac{315}{1+\left(315 \times 0.1^{2}\right)} \\
& \mathrm{n}=\frac{315}{1+(3.15)} \\
& \mathrm{n}=75.90 \approx 76 \text { mahasiswa }
\end{aligned}
$$

Perbandingan jumlah sampel dari masing-masing program studi:

Ekonomi Syariah $=\frac{142}{315} \times 76=34.26 \approx 34$ mahasiswa

Perbankan Syariah $=\frac{173}{315} \times 76=41.73 \approx 42$ mahasiswa

Adapun teknik pengambilan sampel adalah simple random sampling yaitu pengambilan anggota sampel dari populasi secara acak tanpa memperhatikan strata yang ada dalam populasi itu (Sugiyono, 2018).

\subsection{Definisi Operasional}

Definisi operasional atau sering dinamakan juga sebagai operasionalisasi variabel adalah kegiatan atau proses yang dilakukan peneliti untuk mengurangi tingkat abstraksi konsep sehingga konsep tersebut dapat diukur (Zulganef, 2018). Berdasarkan posisi dan fungsinya dalam penelitian, variabel yang akan diteliti dalam penelitian ini terdiri dari dua variabel, yaitu:

a. Variabel Bebas

Variabel bebas adalah variabel yang memengaruhi, menjelaskan, atau menerangkan variabel yang lain. Variabel ini menyebabkan perubahan pada variabel terikat (Muri Yusuf, 2017). Variabel bebas dalam penelitian ini adalah faktor-faktor yang mempengaruhi minat yaitu dorongan dari dalam diri individu $\left(\mathrm{X}_{1}\right)$, motif sosial $\left(\mathrm{X}_{2}\right)$ dan faktor emosional $\left(\mathrm{X}_{3}\right)$.

b. Variabel Terikat

Variabel terikat adalah variabel yang dipengaruhi atau diterangkan oleh variabel lain tetapi tidak dapat mempengaruhi variabel yang lain (Muri 
Yusuf, 2017). Variabel terikat dalam penelitian ini adalah minat investasi di pasar modal syariah.

\subsection{Teknik Analisis}

a. Deskriptif Responden

b. Uji instrumen pada penelitian ini yaitu:

1) Uji Validitas

2) Uji Reliabilitas

c. Teknik analisis data dalam penelitian ini adalah sebagai berikut:

1) Uji Asumsi Klasik

a) Uji Normalitas

a.1) Analisis Grafik

a.2) Analisis Statistik

b) Uji Multikolinieritas

c) Uji Heteroskedastisitas

c.1) Metode Grafik Scatterplot

c.2) Uji Glejser

2) Uji Hipotesis

a) Uji t (Parsial)

b) Uji F (Simultan)

c) Uji Koefisien Determinasi $\left(\mathrm{R}^{2}\right)$

3) Analisis Regresi Linier Berganda

Regresi linier berganda adalah sebuah teknik analisis data untuk mengetahui seberapa besar pengaruh variabel bebas terhadap variabel terikat. Pada regresi linier berganda variabel bebas lebih dari satu variabel (Muhammad M, 2008). Adapun model persamaannya adalah sebagai berikut:

$$
\mathrm{Y}=\mathrm{a}+\mathrm{b}_{1} \mathrm{X}_{1}+\mathrm{b}_{2} \mathrm{X}_{2}+\mathrm{b}_{3} \mathrm{X}_{3}+\mathrm{e}
$$

Keterangan:

Y : Minat Investasi

$\mathrm{X}_{1}$ : Dorongan Dari Dalam Diri Individu

$\mathrm{X}_{2}$ : Motif Sosial

$\mathrm{X}_{3}$ : Faktor Emosional

a : Konstanta

$b_{1}$ : Koefisien regresi variabel $X_{1}$

$\mathrm{b}_{2}$ : Koefisien regresi variabel $\mathrm{X}_{2}$

$b_{3}$ : Koefisien regresi variabel $X_{3}$

e : error term (residu) 


\section{HASIL DAN PEMBAHASAN}

\subsection{Hasil}

a. Karakteristik Demografi Responden

Penelitian ini dilakukan di Fakultas Ekonomi dan Bisnis Islam Institut Agama Islam Negeri Fattahul Muluk Papua di Jl. Merah Putih Buper Waena. Sampel dalam penelitian ini berjumlah 76 responden yang berasal dari mahasiswa Fakultas Ekonomi dan Bisnis Islam IAIN Fattahul Muluk Papua yaitu mahasiswa program studi Ekonomi Syariah dan Perbankan Syariah baik yang sudah memiliki akun investasi ataupun belum. Penyebaran kuesioner dilakukan secara langsung kepada responden. Gambaran mengenai responden yang menjadi sampel penelitian adalah sebagai berikut:

Tabel 2: Karakteristik Demografi Responden

\begin{tabular}{|c|c|c|}
\hline Program Studi & Jumlah Responden & Persentase \\
\hline Ekonomi Syariah & 34 Mahasiswa & $44.74 \%$ \\
\hline Perbankan Syariah & 42 Mahasiswa & $55.26 \%$ \\
\hline Tahun Angkatan & Jumlah Responden & Persentase \\
\hline 2016 & 18 Mahasiswa & $23.68 \%$ \\
\hline 2017 & 21 Mahasiswa & $27.63 \%$ \\
\hline 2018 & 29 Mahasiswa & $38.16 \%$ \\
\hline 2019 & 8 Mahasiswa & $10.53 \%$ \\
\hline Jenis Kelamin & Jumlah Responden & Persentase \\
\hline Laki-laki & 24 Mahasiswa & $31.58 \%$ \\
\hline Perempuan & 52 Mahasiswa & $68.42 \%$ \\
\hline
\end{tabular}

SSumber: Hasil Olah Data Primer, 2020

b. Uji Validitas dan Reliabilitas

Uji validitas dan reliabilitas adalah proses menguji pernyataanpernyataan yang ada di dalam kuesioner, apakah pernyataan-pernyataan yang ada di dalam kuesioner valid atau tidak valid dan reliabel atau tidak reliabel. Pengujian validitas dapat dilakukan dengan teknik korelasi antara setiap faktor atau item dari skor total faktor. Korelasi yang digunakan adalah korelasi Pearson Moment yang dianalisis dengan menggunakan SPSS 16.0. Hasil uji validitas dapat diketahui dengan membandingkan nilai $\mathrm{r}$ hitung dengan $r$ tabel. Berdasrkan uji yang telah dilakukan, semua item pernyataan memenuhi kriteria valid karena $r$ hitung lebih besar dari $r$ tabel.

Sementara itu, uji reliabilitas dapat dilakukan dengan uji Cronbach Alpha. Nilai Cronbach Alpha dapat dikatakan reliabel apabila lebih besar dari r tabel. Berdasarkan hasil uji reliabilitas, dapat dilihat dari tabel 3 bahwa semua variabel dapat diandalkan atau reliabel (Widiyanto, 2014). 
Tabel 3: Uji Reliabilitas Menggunakan Cronbach Alpha

\begin{tabular}{|c|l|c|c|c|}
\hline No & \multicolumn{1}{|c|}{ Variabel } & $\begin{array}{c}\text { Cronbach } \\
\text { Alpha }\end{array}$ & r tabel & Keterangan \\
\hline 1 & $\begin{array}{l}\text { Dorongan Dari Dalam Diri } \\
\text { Individu }\left(\mathrm{X}_{1}\right)\end{array}$ & 0.570 & 0.361 & Reliabel \\
\hline 2 & Motif Sosial $\left(\mathrm{X}_{2}\right)$ & 0.755 & 0.361 & Reliabel \\
\hline 3 & Faktor Emosional $\left(\mathrm{X}_{3}\right)$ & 0.415 & 0.361 & Reliabel \\
\hline 4 & Minat Investasi (Y) & 0.806 & 0.361 & Reliabel \\
\hline
\end{tabular}

Sumber: Hasil Olah Data Primer, 2020

c. Uji Normalitas, Multikolinieritas dan Heteroskedastisitas

Pada penelitian ini menggunakan uji asumsi klasik yang terdiri dari uji normalitas, uji multikolinieritas dan uji heteroskedastisitas. Uji normalitas berfungsi untuk menguji model regresi yang digunakan dalam penelitian. Model regresi yang baik adalah distribusi data normal atau paling tidak mendekati normal (Sulistiyani, 2006). Ada dua cara yang tepat untuk mendeteksi apakah residual berdistribusi normal atau tidak yaitu dengan cara berikut (Ghozali, 2016):

a) Analisis Grafik

b) Analisis Statistik (Kolmogorov-Smirnov)

Gambar 3: Uji Normalitas Histogram

Histogram

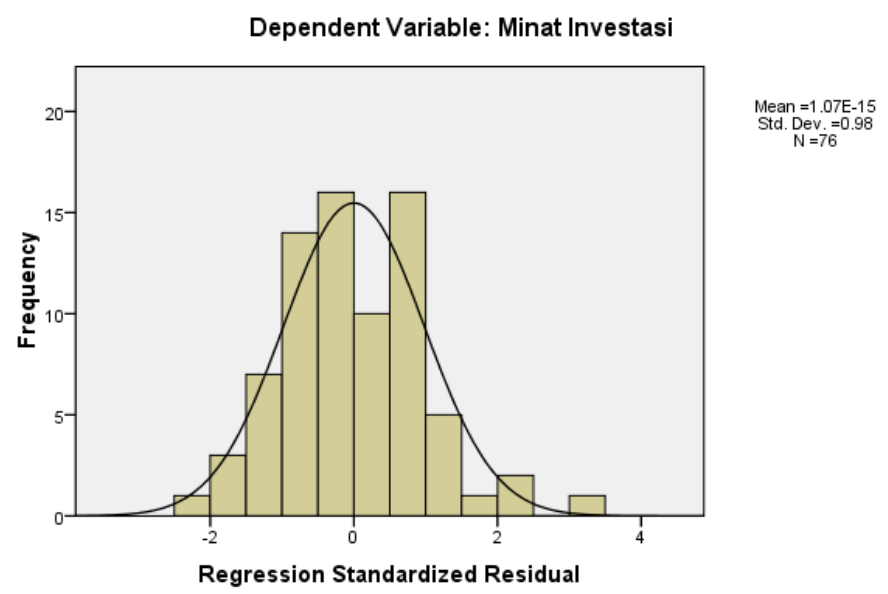

Sumber: Hasil Data Diolah Dengan SPSS, 2020 
Berdasarkan gambar 3, Histogram Regression Residual membentuk kurva seperti lonceng, maka nilai residual tersebut dinyatakan normal atau data berdistribusi normal.

\section{Gambar 4: Uji Normalitas P-P Plot \\ Normal P-P Plot of Regression Standardized Residual}

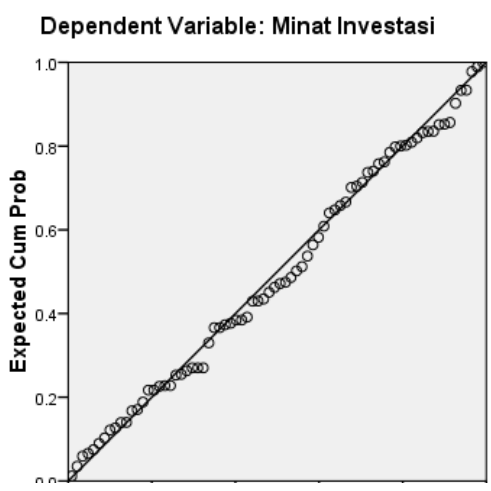

Sumber: Hasil Data Diolah Dengan SPSS, 2020

Tabel 4: Uji Normalitas

One-Sample Kolmogorov-Smirnov Test

\begin{tabular}{|ll|r|}
\hline & & Unstandardized Residual \\
\hline Normal Parameters ${ }^{\mathrm{a}}$ & Mean & 76 \\
& Std. Deviation & .0000000 \\
Most Extreme Differences & Absolute & 1.87155814 \\
& Positive & .063 \\
& Negative & .063 \\
Kolmogorov-Smirnov Z & & -.034 \\
Asymp. Sig. (2-tailed) & & .549 \\
\hline
\end{tabular}

a. Test distribution is Normal.

Sumber: Hasil Data Diolah Dengan SPSS, 2020

Berdasarkan gambar 4, dapat dilihat bahwa titik-titik yang menyebar di sekitar garis diagonal dan penyebaran titik-titik data searah dengan garis diagonal menandakan bahwa model asumsi regresi memenuhi asumsi normalitas dan model regresi layak untuk menganalisis pengaruh variabelvariabel bebas (dorongan dari dalam diri individu, motif sosial, faktor emosional) terhadap variabel terikat (minat investasi). 
Berdasarkan tabel 4 menunjukkan bahwa tingkat signifikansi residual sebesar 0.924. Dapat disimpulkan bahwa model penelitian memiliki distribusi data normal.

Uji multikolinieritas diperlukan untuk mengetahui ada tidaknya variabel bebas yang memiliki kemiripan antar variabel bebas dalam suatu model. Jika Variance Inflation Factor (VIF) yang dihasilkan antara 1-10 dan nilai toleransi > 0.10 maka tidak terjadi multikolinieritas (V. Wiratna Sujarweni, 2015).

Tabel 5: Uji Multikolinieritas

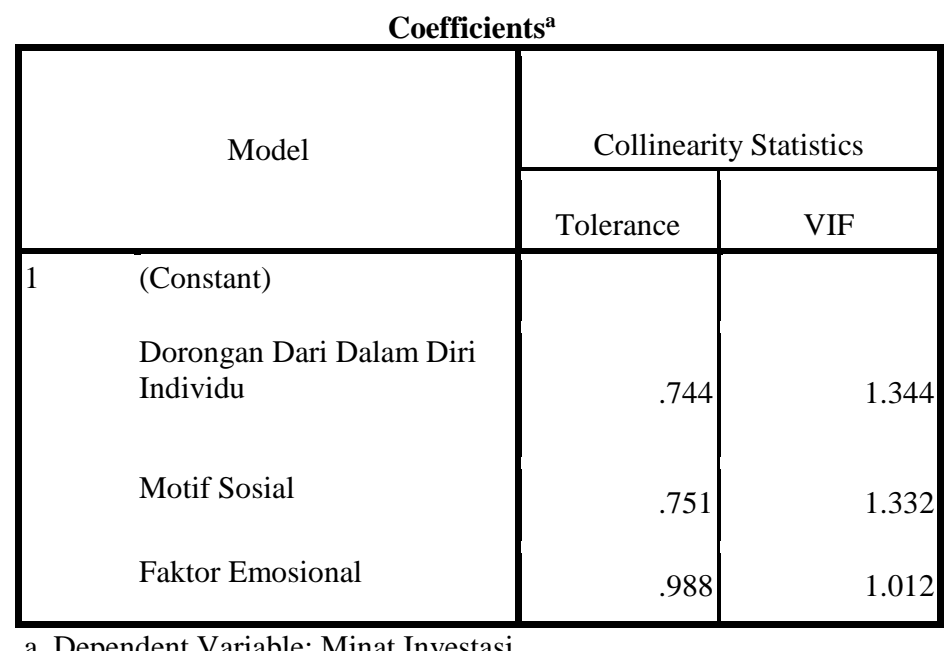

Sumber: Hasil Data Diolah Dengan SPSS, 2020

Berdasarkan tabel 5 masing-masing variabel bebas memiliki nilai tolerance $>0.10$ yaitu variabel dorongan dari dalam diri individu sebesar 0.744, variabel motif sosial sebesar 0.751 dan variabel faktor emosional sebesar 0.988. Sedangkan nilai VIF $<10$ yaitu variabel dorongan dari dalam diri individu sebesar 1.344, variabel motif sosial sebesar 1.332 dan variabel faktor emosional sebesar 1.012, maka dapat dinyatakan model regresi linier berganda tidak terdapat multikolinieritas antara variabel terikat dengan variabel bebas yang lain sehingga dapat digunakan dalam penelitian ini.

Heteroskedastisitas menguji terjadinya perbedaan variance residual suatu periode pengamatan ke periode pengamatan yang lain. Berikut beberapa cara dalam mendeteksi adanya heteroskedastisitas (Imam Ghozali, 2016):

a) Metode Grafik Scatterplot

b) Uji Geljser 


\section{Gambar 5: Uji Heteroskedastisitas Secara Grafik}

Scatterplot

Dependent Variable: Minat Investasi

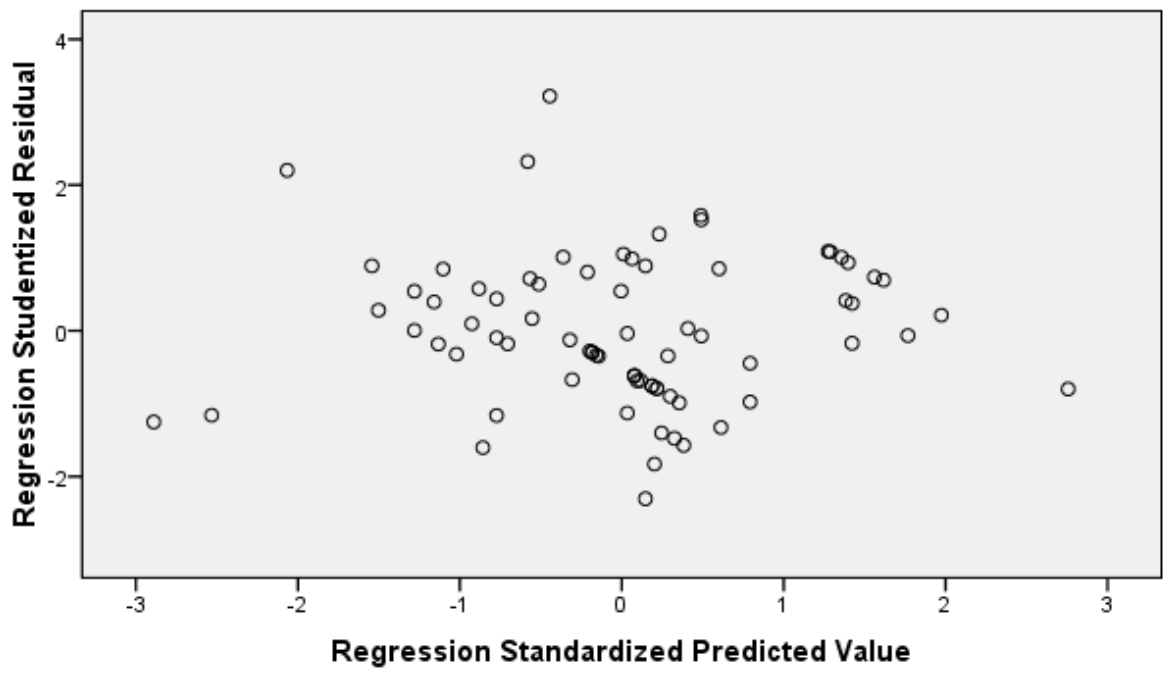

Sumber: Hasil Data Diolah Dengan SPSS, 2020

Berdasarkan gambar 5 dapat disimpulkan bahwa tidak terjadi heteroskedastisitas pada model regresi sehingga model regresi layak digunakan untuk memprediksi minat investasi berdasarkan variabel bebas.

Tabel 6: Uji Heteroskedastisitas Secara Statistik (Uji Glejser)

Coefficients $^{\mathrm{a}}$

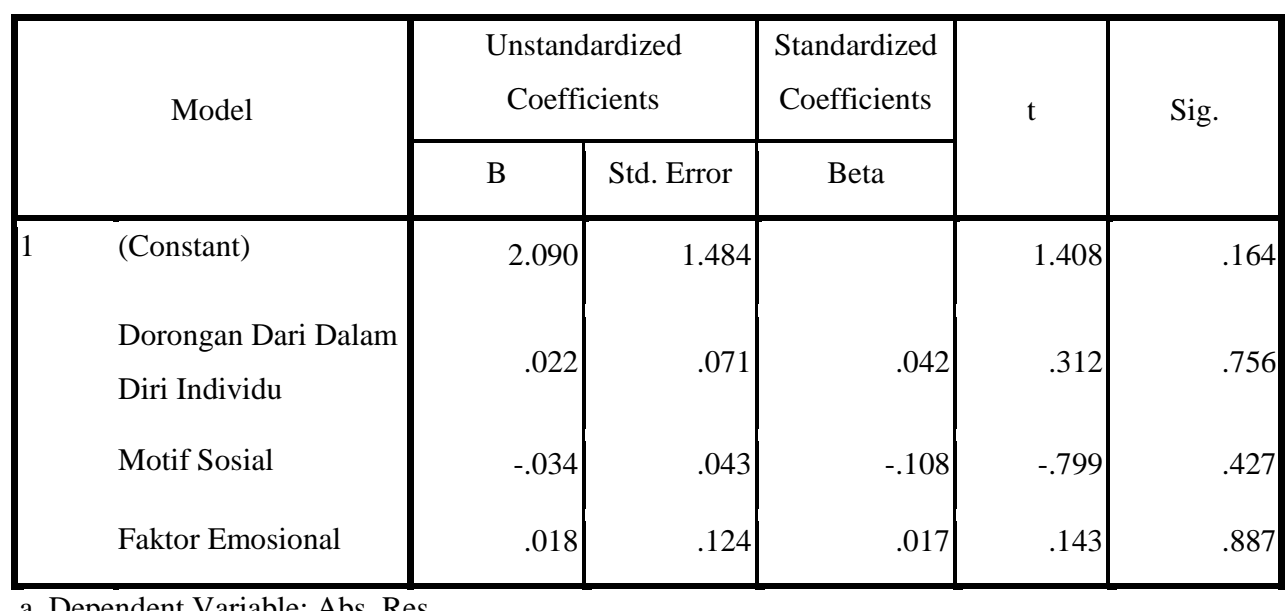

a. Dependent Variable: Abs_Res

Sumber: Hasil Data Diolah Dengan SPSS, 2020

Berdasarkan tabel 6 dapat dilihat bahwa nilai signifikansi untuk variabel dorongan dari dalam individu (X1) sebesar 0.756, variabel motif 
sosial (X2) sebesar 0.427 dan variabel faktor emosional (X3) sebesar 0.887. Karena tingkat signifikansi > 0.05, maka dapat disimpulkan bahwa pada model regresi tidak terjadi heteroskedastisitas.

d. Uji Hipotesis

Tabel 7: Uji Regresi Linier Berganda

Coefficients $^{\mathrm{a}}$

\begin{tabular}{|c|c|c|c|c|c|c|}
\hline & \multirow[t]{2}{*}{ Model } & \multicolumn{2}{|c|}{$\begin{array}{c}\text { Unstandardized } \\
\text { Coefficients }\end{array}$} & \multirow{2}{*}{$\begin{array}{c}\begin{array}{c}\text { Standardized } \\
\text { Coefficients }\end{array} \\
\text { Beta }\end{array}$} & \multirow[t]{2}{*}{$\mathrm{t}$} & \multirow[t]{2}{*}{ Sig. } \\
\hline & & B & Std. Error & & & \\
\hline \multirow[t]{5}{*}{1} & (Constant) & -.749 & 2.487 & & -.301 & .764 \\
\hline & Dorongan Dari & & & & & \\
\hline & Dalam Diri Individu & (40J. & .110 & 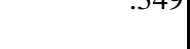 & 4.004 & .000 \\
\hline & Motif Sosial & .449 & .072 & .529 & 6.226 & .000 \\
\hline & Faktor Emosional & -.290 & .208 & -.103 & -1.392 & .168 \\
\hline
\end{tabular}

a. Dependent Variable: Minat Investasi

Sumber: Hasil Data Diolah Dengan SPSS, 2020

Analisis untuk mengetahui faktor-faktor yang mempengaruhi minat investasi di pasar modal syariah pada mahasiswa FEBI IAIN Fattahul Muluk Papua dilakukan dengan menggunakan teknik regresi linier berganda. Penelitian ini menggunakan Dorongan Dari Dalam Diri Individu, Motif Sosial dan Faktor Emosional sebagai variabel bebas, sedangkan variabel terikatnya adalah minat investasi di pasar modal syariah. Hasil regresi menggambarkan bahwa Dorongan Dari Dalam Diri Individu dan Motif Sosial secara signifikan mempengaruhi minat investasi di pasar modal syariah. Sementara itu, variabel lain yaitu faktor emosional tidak memiliki pengaruh terhadap minat investasi di pasar modal syariah. Kesimpulannya ditunjukkan oleh nilai sig. dari masing-masing variabel. Nilai sig. dari Dorongan Dari Dalam Diri Individu dan Motif Sosial adalah $0.000<0.05$, sedangkan nilai sig. dari faktor emosional adalah $0.168>0.05$. 


\section{Tabel 8: Uji F (Simultan)}

ANOVA $^{b}$

\begin{tabular}{|r|r|r|r|r|r|}
\hline \multicolumn{1}{|c|}{ Model } & Sum of Squares & \multicolumn{1}{c|}{ df } & Mean Square & F & \multicolumn{1}{c|}{ Sig. } \\
\hline $1 \quad$ Regression & 410.282 & 3 & 136.761 & 37.482 & $.000^{\mathrm{a}}$ \\
& 262.705 & 72 & 3.649 & & \\
Residual & 672.987 & 75 & & & \\
Total & & & & & \\
\hline
\end{tabular}

a. Predictors: (Constant), Faktor Emosional, Motif Sosial, Dorongan Dari Dalam Diri Individu

b. Dependent Variable: Minat Investasi

Sumber: Hasil Data Diolah Dengan SPSS, 2020

Berdasarkan tabel 8 nilai $\mathrm{F}$ hitung yang diperoleh adalah $37.482>$ 2.73 dan signifikansi $0.000<0.05$. Sehingga dapat disimpulkan bahwa variabel dorongan dari dalam diri individu, motif sosial dan faktor emosional secara bersama-sama (simultan) berpengaruh signifikan terhadap variabel minat investasi.

Tabel 9: Uji Koefisien Determinasi $\left(\mathbf{R}^{2}\right)$

\begin{tabular}{|c|r|r|r|r|r|}
\hline Model & $\mathrm{R}$ & R Square & $\begin{array}{c}\text { Adjusted R } \\
\text { Square }\end{array}$ & $\begin{array}{c}\text { Std. Error of the } \\
\text { Estimate }\end{array}$ & Durbin-Watson \\
\hline 1 & $.781^{\mathrm{a}}$ & .610 & .593 & 1.910 & 1.848 \\
\hline
\end{tabular}

a. Predictors: (Constant), Faktor Emosional, Motif Sosial, Dorongan Dari Dalam Diri Individu

b. Dependent Variable: Minat Investasi

Sumber: Hasil Data Diolah Dengan SPSS, 2020

Berdasarkan tabel 9 dapat diketahui koefisien determinasi $\left(\mathrm{R}^{2}\right)$ dilihat dari kolom $R$ Square sebesar 0.610. Hasil ini berarti variabel bebas yaitu dorongan dari dalam diri individu, motif sosial dan faktor emosional hanya menjelaskan sebesar $61 \%$ terhadap variabel terikat yaitu minat investasi, sedangkan sisanya sebesar 39\% dijelaskan oleh variabel lain yang tidak disertakan dalam penelitian ini. 
Tabel 10: Ringkasan Pengujian Hipotesis

\begin{tabular}{|l|c|c|}
\hline \multicolumn{1}{|c|}{ Hipotesis } & Sig. & Keterangan \\
\hline $\begin{array}{l}\mathrm{H}_{1:} \text { Dorongan dari dalam individu berpengaruh } \\
\text { signifikan dan positif terhadap minat investasi }\end{array}$ & 0.000 & Diterima \\
\hline $\begin{array}{l}\mathrm{H}_{2} \text { : Motif sosial berpengaruh signifikan dan positif } \\
\text { terhadap minat investasi }\end{array}$ & 0.000 & Diterima \\
\hline $\begin{array}{l}\mathrm{H}_{3:} \text { Faktor emosional berpengaruh signifikan dan } \\
\text { positif terhadap minat investasi }\end{array}$ & 0.168 & Tidak Diterima \\
\hline $\begin{array}{l}\mathrm{H}_{4} \text { Dorongan dari dalam individu, motif sosial, } \\
\text { faktor emosional secara simultan berpengaruh } \\
\text { signifikan dan positif terhadap minat investasi }\end{array}$ & 0.000 & Diterima \\
\hline
\end{tabular}

Sumber: Hasil Data Diolah Dengan SPSS, 2020

\subsection{Pembahasan}

Penelitian dilakukan untuk menganalisis faktor-faktor yang mempengaruhi minat investasi di pasar modal syariah pada mahasiswa FEBI IAIN Fattahul Muluk Papua menggunakan teori Crow and Crow tentang beberapa faktor yang mempengaruhi timbulnya minat. Penelitian ini menganalisis tiga faktor sebagai variabel bebas, yaitu Dorongan Dari Dalam Diri Individu, Motif Sosial dan Faktor Emosional. Hasil penelitian menunjukkan bahwa model tersebut dapat menjelaskan $61 \%$ terhadap variabel terikat yaitu minat investasi di pasar modal syariah. Hal tersebut ditunjukkan dari nilai $R$ Square sebesar 0.610. Sedangkan sisanya sebesar 39\% dijelaskan oleh variabel lain yang tidak disertakan dalam penelitian ini.

Hasil penelitian menyimpulkan bahwa dorongan dari dalam diri indivdu memiliki pengaruh yang signifikan dan positif terhadap minat investasi di pasar modal syariah pada mahasiswa FEBI IAIN Fattahul Muluk Papua. Hasil ini juga memiliki kesamaan dengan penelitian yang dilakukan oleh oleh Ahmad Dahlan Malik yang menyatakan bahwa variabel motivasi berpengaruh terhadap meningkatnya pertimbangan pembelian saham syariah di Bursa Galeri Investasi UISI dengan harapan untuk mendapatkan keuntungan berinvestasi di saham syariah, keberkahan, terjaminnya pendapatan yang baik, halal, pengembangan keuangan syariah, dan menjadi pemilik perusahaan yang diinvestasikan.

Hasil penelitian ini juga menyimpulkan bahwa motif sosial memiliki pengaruh yang signifikan dan positif terhadap minat investasi di pasar modal syariah pada mahasiswa FEBI IAIN Fattahul Muluk Papua. Motif sosial yang tinggi dari lingkungan sekitar seseorang akan berdampak lebih besar pula terhadap minat investasi di pasar modal syariah. Hasil penelitian ini berbeda dengan penelitian terkait "Faktor-Faktor Yang Mempengaruhi Minat Mahasiswa Berinvestasi Di Galeri Investasi Syariah Universitas Negeri Makassar" yang dilakukan oleh Sartika Susanti, Muhammad Hasan, M. Ihsan Said Ahmad, dan 
Maharwati menyatakan bahwa secara parsial faktor sosial tidak secara signifikan mempengaruhi minat investasi pada mahasiswa.

Faktor emosional adalah salah satu faktor yang mengarahkan calon investor untuk membuat keputusan apakah mereka ingin atau tidak membuka account investasi syariah. Hasil penelitian menyimpulkan bahwa faktor emosional tidak secara signifikan mempengaruhi minat investasi di pasar modal syariah pada mahasiswa FEBI IAIN Fattahul Muluk Papua. Hasil penelitian ini berbeda dengan penelitian terkait "Faktor-Faktor Yang Mempengaruhi Minat Mahasiswa Berinvestasi Di Galeri Investasi Syariah Universitas Negeri Makassar" yang dilakukan oleh Sartika Susanti, Muhammad Hasan, M. Ihsan Said Ahmad, dan Maharwati menyatakan bahwa secara parsial hanya variabel faktor psikologis yang berada pada taraf signifikansi 0.000 atau mempunyai pengaruh terhadap minat mahasiswa.

\section{KESIMPULAN DAN SARAN}

Penelitian ini bertujuan untuk menentukan faktor-faktor yang mempengaruhi minat investasi di pasar modal syariah pada mahasiswa FEBI IAIN Fattahul Muluk Papua, menggunakan teori Crow and Crow tentang beberapa faktor yang mempengaruhi timbulnya minat sebagai kerangka teori. Penelitian ini menunjukkan dua variabel bebas yang memiliki pengaruh signifikan dan positif terhadap minat investasi di pasar modal syariah yaitu variabel dorongan dari dalam diri individu dan motif sosial. Sedangkan satu variabel bebas yaitu faktor emosional tidak memiliki pengaruh terhadap minat investasi di pasar modal syariah. Hasil penelitian ini dapat berkontribusi sebagai referensi tentang produk investasi syariah untuk menentukan minat investasi di pasar modal syariah, serta sumber informasi bagi pemerintah, lembaga yang terkait dengan penyelenggaraan perdagangan efek di Indonesia, dan pihak lain yang tertarik dengan produk investasi syariah dan pengembangannya. Hasil penelitian ini juga menunjukkan bahwa teori Crow and Crow adalah faktor penentu timbulnya minat, seperti yang disarankan dari penelitian sebelumnya. Hasil penelitian ini menunjukkan bahwa faktor emosional tidak mempunyai pengaruh terhadap minat investasi karena masih tidak ada rasa percaya diri untuk melakukan investasi. Oleh karena itu dapat disarankan kepada lembaga atau pihak penyelenggara perdagangan efek untuk melakukan sosialisasi, edukasi dan pelatihan terkait investasi di pasar modal syariah agar meningkatkan kepercayaan diri tiap individu untuk ikut berpartisipasi dalam kegiatan investasi. Disarankan juga untuk penelitian selanjutnya untuk mengeksplorasi faktor-faktor lain yang mempengaruhi minat investasi di pasar modal syariah untuk memperluas perkembangan produk investasi syariah.

\section{DAFTAR REFERESI}

Anggito, Albi dan Johan Setiawan. (2018). Metodologi Penelitian Kualitatif. Sukabumi: CV Jejak.

Darmawan, Deni. (2016). Metode Penelitian Kuantitatif. Cet. ke-3. Bandung: PT Remaja Rosdakarya. 
Fajri, Hayatul. (2018). Analisis Faktor-Faktor Yang Mempengaruhi Minat Berinvestasi Di Pasar Modal Syariah (Studi Kasus Mahasiswa Program Studi Ekonomi Syariah UIN Ar-Raniry Banda Aceh). UIN Ar-Raniry Banda Aceh.

Ghozali, Imam. (2016). Aplikasi Analisis Multivariate Dengan Program IBM SPSS 23. Edisi ke-8. Semarang: Universitas Diponogoro.

Huda, Nurul, dan Mustafa Edwin Nasution. (2008). Investasi Pada Pasar Modal Syariah. Ed. Revisi. Cet. ke-2. Jakarta: Kencana.

Ikit, Rizal Alfit Jaya, Muhammad Rahman Bayumi. (2019). Bank Dan Investasi Syariah. Yogyakarta: Gava Media.

Karima, Laili. (2018). Analisis Faktor-Faktor Yang Mempengaruhi Minat Mahasiswa Untuk Melakukan Investasi Di Pasar Modal Syariah (Studi Kasus Mahasiswa Fakultas Ekonomi Universitas Islam Indonesia). Universitas Islam Indonesia.

KSEI News Edisi 02. (2019, Apr-Jun), 10.

Kusmawati. (Mei 2011), Pengaruh Motivasi Terhadap Minat Berinvestasi Di Pasar Modal Dengan Pemahaman Investasi Dan Usia Sebagai Variabel Moderat. Jurnal Ekonomi Dan Informasi Akuntansi (Jenius), Vol. 1 No. 2.

M, Muhammad. (2008). Metodologi Penelitian Ekonomi Islam Pendekatan Kuantitatif. Depok: Raja Grafindo.I

Malik, Ahmad Dahlan. (Januari-juni 2017), Analisa Faktor-Faktor Yang Mempengaruhi Minat Masyarakat Berinvestasi Di Pasar Modal Syariah Melalui Bursa Galeri Investasi UISI. Jurnal Ekonomi Dan Bisnis Islam, Vol. 3 No. 1.

Manan, Abdul. (2017). Aspek Hukum Dalam Penyelenggaraan Investasi Di Pasar Modal Syariah Indonesia. Cet. ke-2. Jakarta: Kencana.

Patrianissa, Dinda Ratih. (2018). Faktor-Faktor Yang Mempengaruhi Minat Investasi Di Pasar Modal (Studi Kasus Mahasiswa Fakultas Ekonomi Dan Bisnis Universitas Sumatera Utara). Universitas Sumatera Utara.

Shaleh, Abdul Rahman dan Muhbib Abdul Wahab. (2004). Psikologi Suatu Pengantar: Dalam Perspektif Islam. Jakarta: Prenada Media.

Soetiono, Kusumaningtuti S, dan Cecep Setiawan. (2018). Literasi Dan Inklusi Keuangan Indonesia. Depok: Rajawali Pers.

Sugiarto. Metodologi Penelitian Bisnis. (2017). Yogyakarta: ANDI.

Sugiyono. (2017). Metode Penelitian Kuantitatif, Kualitatif, dan R\&D. Cet. ke-25. Bandung: Alfabeta.

Sugiyono. (2018). Metode Penelitian Manajemen. Cet. ke-6. Bandung: Alfabeta.

Sujarweni, V. Wiratna. (2015). Metodologi Penelitian Bisnis Dan Ekonomi. Yogyakarta: Pustakabarupress.

Sulistiyani, Sri. (2006). 10 Model Penelitian Dan Pengolahannya Dengan SPSS. Yogyakarta: Andi Offset.

Supriyadi, Edy. (2014). SPSS+Amos. Jakarta: In Media.

Susanti, Sartika dan Muhammad Hasan, M. Ihsan Said Ahmad, Marhawati. (2018), Faktor-Faktor Yang Mempengaruhi Minat Mahasiswa Berinvestasi Di Galeri Investasi Universitas Negeri Makassar. Prosiding Seminar Nasional Pendidikan Ekonomi.

Widiyanto, Joko. (2014). SPSS For Windows Untuk Analisis Data Statistik Dan Penelitian. Surakarta: Laboratorium Komputer FKIP Universitas Muhammadiyah Surakarta. 
Yusuf, Muri. (2017). Metode Penelitian: Kuantitatif, Kualitatif, Dan Penelitian Gabungan. Cet. ke-4. Jakarta: Kencana.

Zulganef. (2018). Metode Penelitian Bisnis Dan Manajemen. Bandung: PT Refika Aditama. 